\title{
Menu or Mandate? EU Governance and Party Politics in Poland
}

\section{Pengfei Hou ${ }^{1}$}

Received: 21 May 2019 / Accepted: 13 April 2020 / Published online: 22 April 2020

(c) The Author(s) 2020

\begin{abstract}
This article examines how the European Union (EU) has impacted party politics in Poland. Before the 2004 accession, party politics in Poland were turbulent. In this period, the EU, as a reference point, helped to create a pro- and anti-EU party cleavage. With this impact admitted, the article turns to the post-accession party politics. Centering on the nationalist Law and Justice (Prawo i Sprawiedliwość, PiS), the article attempts to explore the EU's impact on the PiS by studying the latter's adaptation preferences. To do so, I employ James N. Rosenau's political adaptation theory. Central to the article is the argument that since political parties are the protagonists in member states' domestic politics, the EU can only affect the party politics in Poland indirectly, but not inconsequentially. Without mandate notwithstanding, the EU can create bottom-up pressures through civil society; meanwhile, since EU norms and political parties' particular interests are not necessarily incompatible, the EU can take the initiatives to make a balance between them through policy innovations.
\end{abstract}

Keywords The EU $\cdot$ Europeanization $\cdot$ Poland $\cdot$ Political party $\cdot$ Adaptation

Electronic supplementary material The online version of this article (https://doi.org/10.1007/s4111 1-020-00147-0) contains supplementary material, which is available to authorized users.

\section{Pengfei Hou}

ph65@st-andrews.ac.uk

1 School of International Relations, University of St Andrews, Fife, Scotland, UK 


\section{Introduction}

After escaping Moscow's orbit in the late 1980s, Poland has mainly gone through three scenarios; namely, the scenarios of democratization (1989-2001), democratic consolidation (2005-2014) ${ }^{1}$ and autocratization (2015-present). ${ }^{2}$ In each scenario, the European Union (EU) serves as a significant if not the sole reference point.

Concerning party politics, their nature is characterized by the left-right cleavage in Western Europe. However, such party cleavage is ambiguous in Central and Eastern Europe (CEE) in general and in Poland in particular (Morlino 2001: 93). In his categorization of CEE's political parties, Agh (1998) differentiated nationalist parties from the populist strands and labeled them as neo-traditionalist and nationalpopulist parties, respectively. Moreover, Agh believed that nationalist and populist parties are the "twin phenomena" of the "authoritarian renewal" in the early 1990s (1998: 62). That being so, although both nationalist and populist parties are anti-EU in kind, they vary in degree: whereas the nationalist party is moderate, and, hence, center-right, the national-populist party is radical and extreme right.

As to pro-EU parties, although Agh did not give such a label, he, however, observed that there slowly emerged the political elites "with a strong European commitment turning against both neo-traditionalism and national-populism" (Agh 1998: 69). With hindsight, since the elites later established political parties and made themselves "fit the increasingly attractive "pro-EU' space on the political spectrum" (Vachudova 2008: 865), the parties the elites established can be conveniently taken as pro-EU parties in the article.

The article zeros in on the party politics in Poland. Although a generalization of CEE's party politics vis-à-vis the EU is not impossible, the generalization as such risks neglecting different paces and trajectories of party politics in the region. With this in mind, the article centers on Poland, which spearheaded the third wave of democratization, but lagged behind other CEE countries in pace.

\footnotetext{
${ }^{1}$ Subject to different standards, the delineation of democratic consolidation is a complex and controversial issue in all post-communist countries. As far as Poland is concerned, optimists such as Parrott (1997:6) assert that Poland "have reached this watershed, even though controversy persists over the shape of the Polish constitution." However, if "[p]arties and institutionalized party systems are considered the fundamental factor conducive to democratic consolidation and the quality of electoral democracy in particular" (Markowski 2020: 39), the lengthy low turnout alone is adequate to deny the imminent democratic consolidation. In this reading, a clear line can hardly be drawn between democratization and democratic consolidation in Poland. In the article, the 2001-2005 period is taken as a transitional joint in-between. Firstly, the establishments of the PiS and the PO in 2001 began to stabilize the previous turbulent party politics, and such stabilization reached its apogee after the inauguration of the PiS-PO competition in 2005. Secondly, the EU accession in 2004 constituted an institutionally symbolic and significant "'ruptura' with traditionalism-provincialism," and on the heels of such an institution process is democratic consolidation (Agh 1998: 110).

${ }^{2}$ Autocratization can also be understood as democratic backslide, but the article favors the former conceptualization. In a way, autocratization, as a concept, enables us to study the dynamic process wherein a regime is brought closer to a dictatorship (Lührmann and Lindberg 2019: 1099). Therefore, when the backsliding toward authoritarianism, according to Markowski (2020: 46), "notably" began in Poland after 2015, it also inaugurated the autocratization scenario.
} 
The exploration of the EU's impact on Poland's party politics takes 1991 as a convenient starting point. Although the 1989 Round Table Talk triggered Poland's democratization, it is not until 1991 that Europeanization was inaugurated by the association agreement signed between the European Communities and Poland. As per the agreement, the European Community and Poland aimed to regularize political dialogues, through which to "facilitate Poland's full integration into the community."3

The party landscape in Poland began to stabilize after the 2001 parliamentary election. In 2005, alongside the electoral debacle of the post-communist party, the nationalist Law and Justice's (Prawo i Sprawiedliwość, PiS), together with the pro-EU Civic Platform (Platforma Obywatelska, PO) ${ }^{4}$ became the protagonist in Poland's domestic politics. Notably, compared with the PO's pro-EU commitment, the PiS's nationalist credential, at first glance, seems incompatible with EU norms advocating cosmopolitan values. ${ }^{5}$ Be that as it may, the PiS did not behave so; instead, it changed its adaptation preference first by allying with the PO and then with populist parties before heading to the present "soft dictatorship" (Kamusella 2017: 121).

Conventionally, political parties' behaviors should be explained in domestic settings. However, the domestic setting alone is not adequate to understand the PiS's adaptation preferences stated above. When the conventional wisdom fails in grasping the complexity of party politics in the EU's new member states, two compromised approaches stand out. One tends to trivialize or simply neglect the EU's impact; the other turns on the default mode by pigeonholing political parties into the left-right cleavage.

Aiming to understand the driving force behind PiS's change of adaptation preferences, I employ James Rosenau's political adaptation theory. With the analytical traction, the political adaptation theory can help to reveal the otherwise confusing party behaviors. Central to the article is the argument that since political parties are the protagonists in member states' domestic politics, the EU can only affect the party politics in Poland indirectly, but not inconsequentially. Without mandate notwithstanding, the EU can create bottom-up pressures through civil society; meanwhile, since EU norms and political parties' particular interests are not necessarily incompatible, the EU can take the initiatives to make a balance between them through policy innovations.

Before delving into the analysis, both EU governance and Europeanization should be delineated. EU governance is an aggregation of EU norms. As a sui generis administration paradigm, EU governance results from EU integration, and "the fundamental feature of EU governance is its ability to construct Europe as something

\footnotetext{
${ }^{3}$ See Article 2 in the European Union Association Agreement, https://wits.worldbank.org/GPTAD/PDF/ archive/EC-Poland.pdf. Accessed 24 March 2020.

${ }^{4}$ After the 2018 local election, the PO created the Civic Coalition (Koalicja Obywatelska, KO) by forming the parliamentary coalition with the Modern, the Polish Initiative, and the Greens. Nevertheless, the article uses the term "PO" as a general rule.

${ }^{5}$ The EU, as a cosmopolitan polity or power, has been studied by Beck and Grande (2007), Saurugger (2009) and Eriksen (2019).
} 
to be governed" (Delanty and Rumford 2005: 139). Similarly, Europeanization cannot be detached from EU integration, and it refers to the diffusion of policy and institution-a process through which ideas and normative standards spread across time and space (Börzel and Risse 2012: 5). For member states and their political parties, Europeanization is a "meta-power game" (Beck and Grande 2007: 137). Affected by the Europeanization mechanisms of conditionality and socialization, all actors "must redefine their scope and radius of action, their goals and their strategies" (Beck and Grande 2007: 138).

The remainder of the article proceeds in four sections. The first section reviews the past literature on the EU's impact vis-à-vis member states' political parties. The second section examines the political adaptation theory and extends the theory to understand political parties' adaptation preferences. The third section delves into the PiS's adaptation preferences in detail, and the last section concludes by summarizing the article.

\section{Literature Review}

Political parties are vital institutions for democracy (Dalton and Weldon 2007: 179). In new democracies in particular, such as Poland, political parties are essential actors for democratization and its consolidation. The same as many CEE countries, Poland's returning to Europe began in the early 1990s.

The literature on Poland's Europeanization as a candidate state ranges from leadership transformation (Jasiewicz 1997) and party formation (Parrott 1997: 15-21), to constitutional development (Batt and Wolczuk 1998: 90-93). On the contrary, scholarly attention on the EU's impact on the political parties in Poland is meager. As to the reasons, there are mainly two. One is the lack of or late interest in the topics. The research interest in the political party's vis-à-vis European integration, according to Ladrech (2009: 4), only appeared in the late 1970s. Similarly, it was not until after the Cold War that people began to heed the governance approach, and " $\mathrm{t}$ ] he ending of bipolarity also made it possible for more collective management of the world's problems" (Yu 2019: 193).

The other reason is the theoretical incompatibility between EU norms and party politics. The EU is a "post-sovereign normative power" (Merlingen 2007: 438), it, as a new governance variant, "faces a particularly acute set of challenges in naturalizing itself” (McNamara 2015: 1). By contrast, political parties in most countries are still state-centric in nature. Conventionally, political parties should and have to draw their legitimacy in domestic arenas.

For researchers trying to look elsewhere for inspiration, mainstream integration theories, unfortunately, cannot afford the luxury of doing so. From functionalism and intergovernmentalism to constructivism, all theories take states as a fixed reference point. Neofunctionalists prioritize the spillover effect, and integration is taken as a continuous process, wherein "political actors in several distinct national settings are persuaded to shift their loyalties, expectations and political activities toward a new centre" (emphasis in original, Haas 1968: 16). Highlighting the autonomy of states, liberal intergovernmentalists gravitate 
to intergovernmental bargaining and assert that "the pattern of state preferences and power-in particular the opportunity costs of foregoing agreement-is the decisive determinant of specific agreements" (Moravcsik 1998: 52-53). For constructivists, the state has a significant, if not exclusive, role. Therefore, skewing toward the concept, socialization notwithstanding, constructivists emphasize that, in the process of socialization, "domestic politics plays a key, if under-theorized role" (Checkel 2006: 25).

Having said that, the study of the EU's impact on member states' party politics mainly has two pathways. One focuses on the transnational party groups in the European Parliament (EP) (Hix and Lord 1997; Whitaker 2005; Hanley 2008). The Europeanization of political parties in the EU arena gained momentum after the first direct EP elections in 1979 (Ladrech 2009: 4). However, to orthodoxy statists, the party politics in the EP is no more than the sideshow of member states' domestic politics - the presence of party elites is nothing but a failed attempt to reveal the "broader domestic party political dynamics" (Ladrech 2009: 5).

The other pathway treats the EU as one of the many variants. Nevertheless, since member states' political parties cannot be uprooted from the domestic setting, the EU's impact evaluated so is not sanguine. Therefore, for Peter Mair (2000), Europeanization only has a "limited impact" on Western European countries' political parties. Be that as it may, political parties take a late departure in Poland; the EU's impact in Poland does not necessarily follow the same trajectory as that in Western Europe. In other words, although the acquis communautaire has narrowed down the policy space in member states (Dorussen and Nanou 2006; Mair 2007), the "adaptational pressures" are likely to lead to different party behaviors in Poland (Börzel and Risse 2007: 492). Other than that, political parties' adaptations do not always lead to passive convergence or harmonization (Ladrech 2002: 395). Among others, the PiS's increasingly authoritarian tendency is one of the archetypical examples.

For those aiming to evaluate the EU's impact on Poland's party politics, the 2005 elections offered the required feasibility. After the 2005 elections, Poland's party landscape began to stabilize, and the embryonic two-party system formed. In regard to the PiS and the PO in the embryonic two-party system, Szczerbiak and Bil evaluated the EU's impact on them in 2009 and concluded pessimistically. According to them, although "'Europe' has been assimilated successfully into the logic of Polish domestic party politics," the impact of EU membership on Polish parties was "rather minimal" (Szczerbiak and Bil 2009: 450, 455). By minimal, Szczerbiak and Bil explored the EU's impact by looking for how the status of the role of "European policy specialists" had been strengthened and whether there are "new party organizational structures specifically to consider European policy" (Szczerbiak and Bil 2009: 449).

It is worth pointing out that Szczerbiak and Bil's above analysis, with hindsight, set a bar which is too high to give it a fair evaluation. For one thing, the EU has no mandate to impose legal obligations on member states' political parties. For another thing, when the EU's impact has to choose the conduit of civil society, it takes time for civil society to generate adequate bottom-up pressures with which to affect the party politics in Poland. Therefore, not only is such an evaluation premature, but it has also underestimated the EU's impact. With this point in mind, I will reassess 
the EU's impact on the political parties in Poland by examining the PiS's adaptation behaviors from 2001 to 2019.

Not least, to measure the EU's impact on political parties, political parties' adaptation behavior should be differentiated from the act of learning. Whereas the ultimate purpose will be redefined in learning, the emphasis of adaptation "is on altering means of action, not ends" (Haas 1990: 3). Moreover, insofar as adaptation asks for fewer changes or less degree of change, "[t]he very nature of institutions is such that the dice are loaded in favor of the less demanding behavior associated with adaptation" (Haas 1990: 37).

\section{Political Adaptation Theory}

To understand the general patterns of nation-states' foreign policy choices, Rosenau (1981) developed the political adaptation theory. The political adaptation theory starts with the concept of "essential structures." According to Rosenau (1981: 38), essential structures refer to "the interrelated patterns that constitute the basic political, economic, and social life of a national society." In any nation-state, its essential structure allows a limited degree of change. Meanwhile, although the political adaptation theory applies to a range of actors, such as individuals, parties, states, or societies, Rosenau only expounded it in nation-states. That being so, to explore the dynamics behind political parties' adaptation preferences, I will review the theory before extending it to understand political parties' behaviors.

\subsection{Nation States and Adaptation}

Taking nation-state as the point of reference, Rosenau divides changes into two kinds: internal and external changes, each of which has personnel, political, and socioeconomic dimensions. The personnel dimension "refers to the shifts in the identity of the people who occupy the governmental and non-governmental leadership roles" (Rosenau 1981: 44). The political dimension occurs either between government officials or between government officials and the citizenry. Concerning the socioeconomic dimension, it includes a broader domain ranging from the change of production modes to the enactment of new welfare policies.

In line with the above delineation, Rosenau further categorizes nation-states' status quo into four styles. Namely, the convulsive style, the spirited style, the deliberative style, and the habitual style. The convulsive style is characterized by high internal and high external changes. "The combination of high change at home and abroad tends to make established policies and procedures unreliable" (Rosenau 1981: 49). On the contrary, the habitual style has low internal and low external changes. As far as the necessity of changes is concerned, "the rouitinized decision-making processes of governments will suffice to cope with the course of public and world affairs" (Rosenau 1981: 47). If the convulsive and habitual styles are the opposite endpoints of the spectrum, sitting between are the spirited and deliberate styles. The spirited style has low external change and high internal 
Table 1 Relative potencies of four clusters of independent variables as sources of national adaptation

\begin{tabular}{lllll}
\hline Relative potency & $\begin{array}{l}\text { Acquiescent adapta- } \\
\text { tion }\end{array}$ & $\begin{array}{l}\text { Intransigent adapta- } \\
\text { tion }\end{array}$ & $\begin{array}{l}\text { Promotive adapta- } \\
\text { tion }\end{array}$ & $\begin{array}{l}\text { Preservative adap- } \\
\text { tation }\end{array}$ \\
\hline HIGH & Systemic & Societal & Individual & $\begin{array}{l}\text { Systemic } \\
\text { Societal } \\
\end{array}$ \\
LOW & Societal & Systemic & Systemic & Governmental \\
& Individual & Individual & Societal \\
Governmental & Governmental & Governmental & \\
& & & & \\
\hline
\end{tabular}

Source: Rosenau (1981: 81)

change. In contrast, the deliberate style has the reverse paradigm; namely, the fluctuation of external change is high, and that of internal change low.

Foreign policy is "any behavior that a national society directed toward its external environment which, through feedback, does or does not contribute to keeping the fluctuations in its essential structure within acceptable limits" (Rosenau 1981: 58). In this light, foreign policies appropriately adapted to changes can help to contain fluctuations without threatening essential structures. Applying the above adaptation styles to understand nation-states' foreign policy preferences, Rosenau (1981: 58-59) presents four types of adaptation position:

Acquiescent adaptation a society can attempt to keep its essential structures by making them consistent with the changes and demands emanating from its present environment.

Intransigent adaptation a society can seek to render its environment consistent with its present structures.

Promotive adaptation a society can attempt to shape the demands of its present structures and its present environment to each other.

Preservative adaptation a society can seek to live within the limitations that its present structures and its present environment have imposed on each other.

A nation-state's adaptation preference is not static, and the necessity to adapt mainly depends on how the essential structure can be sustained. Therefore, to help to understand such necessity, four variables have been given: the individual, governmental, societal, and systematic variables. Contingent on the relative potency of each set of variables, nation-states' adaptation positions can be triggered to change.

Briefly reviewed, the individual variables encompass decision-makers' value, talents, and prior experiences. The governmental variables refer to the influence of a government's structure on foreign policy choices. The societal variables include the non-governmental aspects of society, such as the degree of national unity and the level of industrialization. Concerning the systemic variables, it includes "any nonhuman aspects of a society's external environment or any actions occurring abroad that condition or otherwise influence the choices made by its officials" (Rosenau 1980: 129). With the high-low axis added, the potency of each set of variables can, in a way, reveal the tendency of nation-states' adaptation preferences (see Table 1). 
Notably, in the systemic variables, geographical proximity is one of the most evident and decisive factors. When the geographical factor plays a primary role in the systemic variables, the potency of the other three variables will be eclipsed. In consequence, the acquiescent position stands out. If it is the societal variables that play a more crucial role than the other three, it points to the intransigent position. In the promotive position, the individual variables have a relatively higher potency than the other three; by contrast, in the preservative position, the individual variables have a relatively lower potency.

Since the relative potency of each set of variables is in constant fluctuation, so is the probability of the change of adaptation position. With all probabilities considered, each of the four adaptation positions has three designations. According to Rosenau (1981: 87), three out of twelve possibilities occur in high probability, and all three are designated to the preservative position. As to the reasons behind this coincidence, it can be attributed to nation-states' burgeoning nationalism and their unwillingness to bargain (Rosenau 1981: 84-85). Three pathways of high probability aside, another three are less likely to occur. One is the pathway from the acquiescent position to the promotive position. The other two have the same preservative departure, but one ends in the acquiescent position, the other the promotive position. Except for the above six possibilities, the other six are hardly possible to occur.

\subsection{Political Parties and Adaptation}

As stated, although the political adaptation theory can also apply to other actors, Rosenau has mainly used it to explain nation-states' foreign policy preferences. As far as political parties are concerned, he only cursorily mentions that electoral competition has a "much lesser extent" influence on internal political changes than that can be released by coups d'état (Rosenau 1981: 43).

Party politics and political parties' adaptation preferences are worthy of studying for two reasons. One is because the ruling party or party coalition steers domestic politics in most countries. Whenever in power, political parties are "central actors in the workings of national democratic governance" (Ladrech 2007: 956). In particular, in a one-party country, the political party can be the only legitimate one to do so through the proxy of government. The other is of the urgency of such a study. When populist politics began gaining momentum in recent years, the CEE countries were the hotspots of populist revival (cf. Pirro 2014). In an authoritarian regime, the long arm of party politics plays a decisive role in formulating state politics. In this light, to better understand an authoritarian regime's behaviors in the international arena, we should also take into account the ruling political party's adaptation position.

Notwithstanding nation-states intertwine with political parties in the national arena, they, as the institutionalized forms of collective interests, differ in size and the degree of homogeneity of political interests. The nation-state is the biggest community in the present state-centric framework, and the interests within are heterogeneous. As to political parties, they are subunits in nation-states and mostly organized out of the same or similar political interest. Insofar as the adaptation capability is concerned, "political entities, and especially large communities and societies, 
are highly adaptive" (Rosenau 1981: 9). In this light, nation-states should be more capable in terms of adaptation than political parties. Meanwhile, political interests in nation-states are more heterogeneous; by contrast, political parties are mostly formed out of a particular set of interests, while the narrower scope of interests has confined their flexibility of adaptation.

More fundamentally, since legal sovereignty can guarantee their existence in the contemporary international setting, nation-states are less worried about the survival issue; as to political parties, there is no such ready-to-take provision in any given national arena. As a result, political parties ill-functioned are more likely to recede into debilitation or dissolution. Especially in new democracies, such as Poland in the early 1990s, the come-and-go of political parties was even more frequent. Furthermore, due to the lack of such provision, political parties striving to keep themselves afloat compete with each other ferociously in electoral competitions. When elections held at intervals are a matter of life and death, each election is a litmus test for political parties' adaptation capability.

Taken together, compared with nation-states, political parties are smaller in size, homogenous in interest, and lower in terms of the odds of survival. Therefore, political parties' adaptation preferences have two comparatively different features of their own. Firstly, political parties pursuing the narrow scopes of interests have less flexibility to change their adaptation preferences. Thus, for any political party pursuing national power, the political stance is pivotal. Secondly, and seemly paradoxically, out of the sheer worry about their survival, political parties are inclined to interpret their agenda flexibly if not entirely freely. ${ }^{6}$ Among others, the PiS in Poland, as will be expounded later in detail, is exceptionally skilled in balancing between the political stance and the adaptive flexibility.

In the European setting, the EU constituted and still constitutes a new reality for new member states' political parties. As one of the significant elements in systemic variables, the EU's impact on member states' political parties, conceivably, was compelling, be it positively or negatively. The pressure emanating from the EU lost its intensity when candidate states acquired the membership. Nevertheless, the continuous Europeanization and the growing power of civil society still play a role in holding political parties accountable, albeit of less intensity. Therefore, it is no exaggeration to say that the systemic variables have an all-time high potency, and major political parties in the candidate states were mainly at the acquiescent position.

Departing from the acquiescent position, political parties' change of adaptation preferences has two possibilities. One is the pathway of high probability. The systematic variables aside, if both the societal and governmental variables also gain relatively high potency, the acquiescent position will be more likely to be shifted to the preservative position. Whenever a political party is set to the preservative position, it is inclined to adapt to EU norms by preserving the existent balance at a particular point. The other is the pathway of low probability. When the individual variables surpass the systemic variables in terms of relative potency, the acquiescent position

\footnotetext{
${ }^{6}$ In theory, political parties can adapt to new reality either by shifting their interest from the old to the new ones, or by merely shoving new reality into the existent framework.
} 
Table 2 National election results in Poland, 2005-2019

\begin{tabular}{|c|c|c|c|c|c|c|}
\hline National elections & 2005 & 2007 & 2010 & 2011 & 2015 & 2019 \\
\hline $\begin{array}{l}\text { Parliamentary } \\
\text { (with voter } \\
\text { turnout) }\end{array}$ & $\operatorname{PiS}^{\mathrm{a}}(40.57 \%)$ & $\mathrm{PO}^{\mathrm{b}}(53.88 \%)$ & & $\mathrm{PO}^{\mathrm{c}}(48.92 \%)$ & PiS (50.92\%) & PiS (61.74\%) \\
\hline Presidential & PiS & & $\mathrm{PO}$ & & PiS & $\mathrm{PiS}$ \\
\hline
\end{tabular}

Source: Compiled by the author from the National Electoral Commission (Państwowa Komisja Wyborcza), https://wybory.gov.pl

${ }^{a}$ After a failed negotiation with the PO, the PiS formed a coalition government with the populist SRP and LPR in 2006

${ }^{\mathrm{b}}$ After the retreat of the SRP, the PiS's coalition government dissolved; the PO formed a coalition government with the pro-EU Polish People's Party (Polskie Stronnictwo Ludowe, PSL)

${ }^{\mathrm{c}}$ The PO kept the coalition with the PSL

will turn to the promotive variant. In the promotive position, the leader of the ruling political party tends to reach a new balance between EU norms and the party interest.

\section{PiS's Adaptation: Janus-Faced Party Behaviors}

The prospective EU membership has been "both a passively influential set of incentive structures which have shaped and conditioned the behaviour of Polish political elites, and an active agent of political reform" (Steves 2001: 340). In the preaccession context, the PiS established in 2001 was no exception. Before the 2005 elections, not only did the PiS have to accept the ex-ante EU membership, but also heed the imminent threat emanating from populist parties as well. Navigating "the political discourses of technocracy, populism, and nationalism" (Grzymala-Busse and Innes 2003: 67), the PiS first allied with the pro-EU PO, and then turned to the populist camp before heading to the soft dictatorship in 2015. As a nationalist party, the flexibility of PiS's adaptation is as remarkable as mythical. To unravel the myth, PiS's party behaviors will be examined against the ex-ante EU backdrop.

\subsection{PiS's Journey to Soft Dictatorship}

Before examining the PiS's adaptation preferences, we have to note three points. First, Poland has long been afflicted by low voter turnout. Although it recorded a historic high rate in the 2019 parliamentary election (61.74\%, see Table 2), low turnout had been a lengthy problem in Poland, and it constitutes, to borrow Dwight Dean's (1960) word, an "anomaly" in a democracy. ${ }^{7}$

\footnotetext{
7 In the analysis of political apathy in US politics, Dwight Dean (1960: 186) claims, "In a democracy, it is an anomaly that only 50 percent to 65 percent of the adult citizens participate even to the minimum extent of voting in presidential elections."
} 
Secondly, it pertains to PiS's paternalist nature. As observed by Agh (1998: 62), "The moderate conservatives focus on the representation of the whole 'nation,' by which they mean the national state in a paternalistic-statist approach." With no exception, the PiS squarely fit the paternalist type; its party programs are built "on the belief of a strong and sovereign Poland with a strong leader and a paternalistic state" (Lázár 2015: 224). One step further, due to the low turnout, the constrained potency of the societal variables has further strengthened the PiS's paternalistic nature.

Thirdly, only through winning elections can the PiS have the chance to set the domestic agenda. Notwithstanding its emergence in 2001, Poland was not prepared for the PiS's administration before the SLD's electoral debacle in 2005. In between, the PiS had to keep itself afloat vigilantly. At that stage, alongside the relative high potency of the EU in the systemic variables, the defunct societal variables, the suppressed governmental and individual variables had driven the PiS to the acquiescent position, albeit not ideally. ${ }^{8}$

Alongside Poland's accession in 2004, the PiS had no other choices but to admit and accept the EU's impact, albeit in a passive manner. Be that as it may, the passive acceptance did not necessarily imply that the PiS could ally with the pro-EU PO automatically. Under the SLD administration, it was when it aimed to manage populist parties' ascendency that the PiS chose to do so actively. Even so, the alliance was short-lived. Right before the 2005 elections, the core difference immediately pitted the PiS against the PO. Concerning the disparate interests:

The PO emphasized its commitment to individual liberties, procedural democracy, and entrepreneurial freedom as the basis of economic growth. The PiS, on the contrary, stressed the need to nourish a national community based on shared values and traditions, with the principles of social solidarity as the basis for public policy. It also utilized expressions of economic nationalism, often with a Euro-skeptic bent (Jasiewicz 2008: 8).

Going one step further, after 2005, the PiS turned to the populist camp for support. As a result, the PiS's Eurosceptic tone was inevitably intensified (Markowski and Tucker 2010: 528). To explain the PiS's growing Eurosceptic inclination and the subsequent alliance with the populist camp, it is worth examining the Polishness that the PiS frequently claimed and persistently clung to.

No matter how elusive it may sound or seem, the Polishness had been underlined by the Polish language and Catholic belief in the 1997 constitution. In regard to the PiS, it had a two-step stratagem to defend the Polishness. Firstly, the PiS criticized the Third Republic after 1989 as "un-Polish, non-national"; subsequently, it aimed to build the Fourth Republic (IV Rzeczpospolita) exclusively on the Polishness. ${ }^{9}$ As elucidated by Frances Millard (2006: 1016):

\footnotetext{
8 The PiS acquiesced EU integration with a harsh standpoint on agrarian issues, such as subsidy and land-purchasing (Zuba 2009: 332).

9 The first Polish republic lasted from 1569 to 1795; the second, 1918-1939.
} 
The Fourth Republic would experience moral cleansing through deep lustration, anti-corruption measures, and reaffirmation of Catholic values; its new Constitution would repair the state; it would heal society with a social contract, including fundamental changes in social and economic policy. This new beginning would rid Poland of the enduring legacy of the Round Table negotiated in 1989 between the regime and Solidarity.

After 2005, the relative potency of PiS's governmental and individual variables increased concomitantly. Concerning the EU factor in the systemic variables, although the EU in the PiS administration had a weakened role, its potency had not become irrelevant. By antagonizing the EU, the PiS headed in the Eurosceptic direction. For instance, after rejecting the Charter of Fundamental Rights at the EU Summit in 2007, the then PiS Prime Minister, Jarosław Kaczyński, took the refusal-tosign action as a remarkable achievement for Poland (Wronski 2007: 7).

As reviewed above, the departure from the acquiescent position has two possible pathways: one is the high probable preservative position, the other the low probable promotive position. The PiS followed the preservative pathway, and this change took time to complete. From 2005 to 2014, the PiS witnessed a gradual dissipation of the potency of the individual variables.

After winning the 2005 elections, the PiS's leadership was first undermined by the intraparty strife, which led to the high-ranking party members' rebellion. Later, since the allied populist parties were felt as being treated as second-rate entities, the resultant resentment led to their retreat from the PiS alliance (Moroska and Zuba 2010: 4). More tragically, the 2010 Smolensk plane crash resulted in the loss of 96 high-ranking officials, including the then-president, Lech Kaczyński.

Alongside the erosion of its leadership, the PiS first failed in the 2007 parliamentary election and then the 2010 presidential election. In this period, the relative potency of the individual variables was gradually weakened; likewise, the potency of the governmental variables decreased as well after the cohabitation period starting from 2007. ${ }^{10}$ Meanwhile, the relative potency of the systemic variables remained high, and the lasting "EU-entry hype" even helped the PO to form a coalition government with the PSL in 2007 (Visvizi and Tokarski 2014: 456).

In explaining why states bandwagon, Schweller (1994: 92) argues, "Like a ball rolling down an incline, initial success generates further success, not greater resistance." Steeped in electoral competitions no less fierce than interstate competitions for national interests, party politics, through electoral outcomes, can also set positive feedback in motion. Dating back to 2007, the PO added as many as 16 paragraphs of EU policy in the election manifesto, which stood in sharp contrast to the absence of any EU policy in 2001 and 2005, respectively (Szczerbiak and Bil 2009: 454). By playing the EU card, the PO achieved consecutive victories in 2007 and $2010 .^{11}$

\footnotetext{
${ }^{10}$ Cohabitation refers to the situation "where a president from one party holds power at the same time as a prime minister from an opposing party and where the president's party is not represented in the cabinet [or parliament in the Polish case]" (Elgie 2010: 29).

${ }^{11}$ Moreover, the PO's leader at that time, Donald Tusk, was appointed as the President of the European Council in 2014.
} 
If the EU factor was essential for PO's successive triumphs, the ensuing Eurozone crisis turned the tables by favoring the PiS. "The Eurozone crisis and its implications for the credibility of the single currency increased the transaction costs of the policy reform process in Poland, thus reinforcing the negative spillovers already in place" (Visvizi and Tokarski 2014: 462). With the support of the populist media, such as Radio Maryja, ${ }^{12}$ The PiS's "linguistic vulgarisms" ended with a landslide victory (Markowski 2016: 1319). Taking more than half of the parliament seats $(51.09 \%)$, the PiS, for the very first time in the post-communist era, formed a majority government.

After the PiS's victory in 2015, the individual variables exceptionally stood out. In Poland, as pointed out by Kamusella, both the Prime Minister and President are the nominal leaders, "but de facto they take orders from and invariably bow to the will and wishes of the PiS chairman" (Kamusella 2017: 121). After driving Poland into the autocratization scenario since 2015, Jarosław Kaczyński, together with the Hungarian leader Viktor Orbán, "are two of the most frequently cited examples of the growth of personalism in European politics. And this expansion is poised to accelerate" (Kendall-Taylor et al. 2017: 8).

Overshadowed by the exceptionally high potency of the individual variables notwithstanding, the potency of systemic variables had been dented by the EU, beleaguered first by the economic crisis and then by the migrant crisis. Concerning the EU's migrant quota, the PiS refused to make any concession. Even before the EU appealed for collective actions, the migrant issue had already been over-politicized. Before the 2015 elections, when the then PO government expressed the willingness to take 2000 or more refugees, Jarosław Kaczyński acrimoniously blamed Germany for "creating...the powerful social magnet for economic immigrants" (Łaszczuk 2015).

Likewise, the governmental variables after 2015 have also hemorrhaged its potency. Among others, the constitutional court crisis had significantly reduced the PiS government's accountability. In the 2015 constitutional court crisis, the PiS interpreted Polishness by favoring the narrowly defined party interests and nullified the PO's appointments of three constitutional tribunal judges. Raising awareness of the PiS's recklessness, the European Commission not only launched proceedings against Poland under Article 7.1 of the Lisbon Treaty but also warned, "there is a clear risk of serious breach of the rule of law in Poland" (European Commission 2017).

To conclude, after the 2015 elections, both the systemic and governmental variables were eclipsed by the exceptionally high potency of the individual variables, and the societal variables were only partially functional. In consequence, the PiS shifted from the preservative position to the promotive position. Notably, although the change from the preservative position to the acquiescent position has a certain

\footnotetext{
12 Due to the underdeveloped civil society, public media has played a decisive role in party politics. Therefore, it is no surprise that the PiS intended to control the state media in 2016. https://www.bbc. co.uk/news/world-europe-35257105. Accessed 24 March 2020.
} 
probability albeit low, this pathway was simply blocked due to the relatively weakening of the EU role in the populist setting.

\subsection{Governance Levels of the EU and Polish Parties}

Due to its discursiveness and complexity, the level of governance is hard to be gauged. As to the measurement of the EU's impact on party politics in Poland, the Worldwide Governance Indicators (WGI) are chosen. In this aspect, the Venice Commission, as the Council of Europe's advisory body on constitutional matters, has also issued the Code of Good Practice (CGP). Although the CGP aims "to offer political parties guidelines stemming from the common and best practice in Europe" (Venice Commission 2009: 5), it is more of guidance on paper than in practice. Therefore, notwithstanding the emphasis on the principles of Rule of law, Democracy, Non-discrimination, Transparency and openness, the CGP has offered no means for evaluation. By contrast, the WGI has specific parameters to understand the quality of governance.

The WGI was produced by Daniel Kaufmann and Aart Kraay (2019), and financed and publicized by the World Bank. Due to the lack of a better alternative, the WGI has been widely used by donor governments to monitor aid recipient countries' governance quality (Thomas 2010: 34). Although there is no causal link between the CGP and the WGI, their underlying principles overlap in one way or another. Specifically, the WGI's indicator of Rule of Law has been selected as one of the standards for the CGP (Venice Commission 2016: 35).

In the WGI, governance is broadly defined as "the traditions and institutions by which authority in a country is exercised" (Kaufmann et al. 2011: 222), which comprises three dimensions, as below:

(a) the process by which governments are selected, monitored and replaced;

(b) the capacity of the government to effectively formulate and implement sound policies;

(c) the respect of citizens and the state for the institutions that govern economic and social interactions among them.

Furthermore, each of the above three areas has two measures: (a) Voice and Accountability, Political Stability and Absence of Violence/Terrorism; (b) Government Effectiveness, Regulatory Quality; (c) Rule of Law, and Control of Corruption (Kaufmann et al. 2011: 223).

Insofar as the feasibility of such measurement is concerned, two extra points should be noted. Firstly, the governance level of the EU (see Fig. 1) in the article has been calibrated to the average level of the EU's founding member states, which include Belgium, France, Italy, Luxemburg, Netherlands, and Germany (then West Germany). "The full members at the core of the EU - its founding members, originally-define the EU's standard of good governance" (Schimmelfennig 2016: 793). In each founding member state, its governance is calculated by averaging the values 


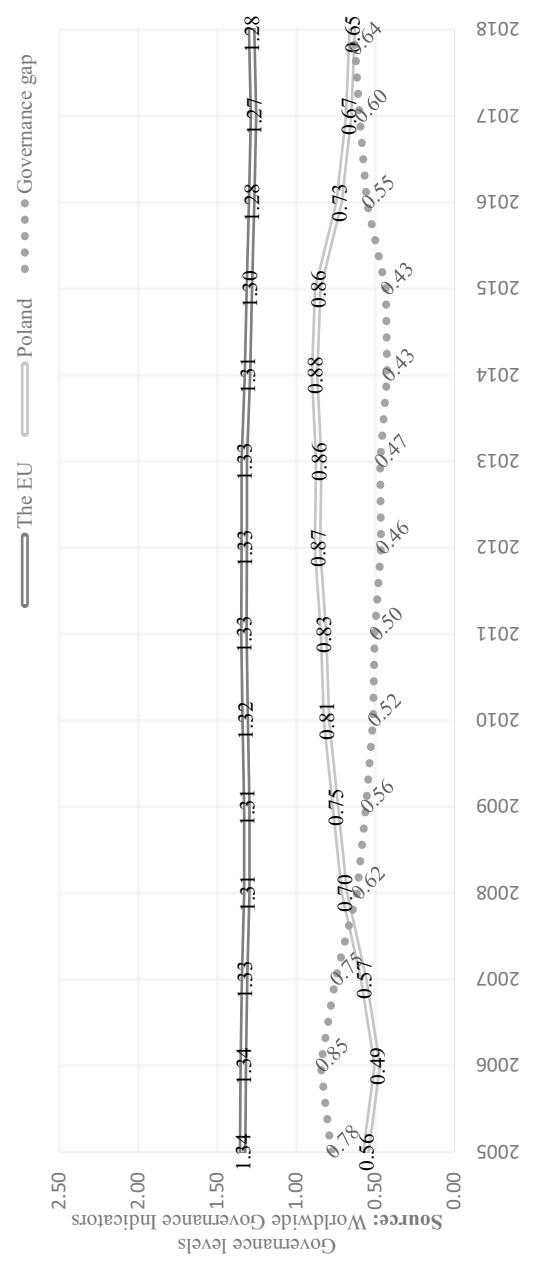

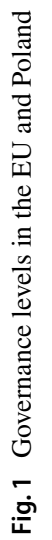


of all six indicators, and the value of each indicator ranges from -2.5 (weak) to 2.5 (strong). ${ }^{13}$

Secondly, the overall level of governance should be interpreted at intervals. In a parliamentary democracy, "governments are composed mainly of the members of the elites of those parties which win the elections" (Blondel 2002: 235). In Poland, the parliamentary system might be kept decent on paper. However, it has been deformed in practice - the arm's length between party and government has been shortened or entirely cut, especially in the PiS government. Therefore, Poland's governance level can largely reflect the ruling political party's governance level. In sequence, Poland's governance level in 2005-2007 mirrored the PiS's performance, and that in 2007-2010 reflected the party governance level in the cohabitation period; the PO's in 2010-2015; the PiS's, again, from 2015 onward.

As revealed by the above graph, the EU's governance level decreased slightly from 2005 to 2018 with the growing populism and the concomitant resentment resulting from EU's austerity rules as possible reasons to explain the drop (Börzel 2016: 17). Concerning the overall governance level in Poland, it lags behind that of the EU. The most significant gap occurred in 2006 (0.85) when Poland's governance level fell to the lowest point (0.49). Not coincidently, it was in 2006 that the PiS organized a coalition government with the populist camp. From 2007 onward, Poland's governance level more or less kept an upward trend until it reached a peak in 2014 (0.88). Concomitantly, the smallest gap has also been recorded in the same $(0.43) .^{14}$

After 2015, the PiS had no more need to negotiate coalition partners, and its increasing authoritarian inclination has resulted in a continuous fall of governance level. Be that as it may, it is worthy of pointing out that the PiS's governance level in 2018 (0.65) overtook that in 2005 (0.56). To explain the improvement, the EU's impact, among others, is not inconsequential.

Lastly, as also admitted by Kaufmann et al. (2011: 242), "any observed empirical measure of governance will only be an imperfect proxy for the broader dimensions of governance that it reflects, and the data informing the WGI are no exception." Considering the complexity of party politics in Poland, we have to admit that the above graph has not revealed the whole picture of Poland's party governance levels. Nevertheless, the WGI, an analytical lens, has allowed us to examine the otherwise hardly measurable governance level; hence we shall judge the WGI on its own merits.

\footnotetext{
${ }^{13}$ Since the values of all countries concerned are above zero, the minimum bound in Graph 1 starts with value zero.

${ }^{14}$ Although the smallest gap (0.43) has also been recorded in 2015, as revealed in Graph 1, it is a technical error. Since the value in the graph follows the rule of two decimal places, the value in $2015(0.4336)$ is the round-down result, while that in $2014(0.4255)$ the round-up result.
} 


\section{Conclusion}

Trying to explore the EU's impact on Poland's party politics in general and the dynamics behind PiS's party behaviors in particular, I employ Rosenau's political adaptation theory in the article. From its establishment in 2001 to the latest parliamentary election in 2019, the PiS, from the acquiescent position, changed its adaptation preferences at least twice. The first change was from the acquiescent position to the preservative position after the 2005 elections. As a result, the PiS, previously allying with the PO, turned to the populist camp for support. The second change mainly occurred after the 2015 elections. After the historic victory in the parliamentary election, the PiS changed from the preservative position to that of promotive.

Notably, behind each PiS change is the ex-ante backdrop of Europeanization. Although the EU aimed to establish certain norms as "consensual knowledge" (Haas 1997: 326), it, as the second point of reference, could only play an indirect role to affect member states' party politics. Be that as it may, the indirect impact does not mean its irrelevance. Firstly, the EU helped to create the pro- and anti-EU party cleavage in Poland and now it is in the process of creating bottom-up pressure by nurturing the power of civil society in Poland.

As an analytical framework, Rosenau's political adaptation theory can explain the otherwise seemly capricious party behaviors. By gauging the fluctuation of the potency of four variables, the study of PiS's adaptation preferences has revealed how its nationalist narrative has fed on the EU norms. Of course, the theory itself has limitations as well. As pointed out by Smith (1981: 202), the political adaptation theory is "not very good at prediction." In this aspect, extending the political adaptation theory to under party politics cannot circumvent this defect. Be that as it may, this article mainly examines the PiS's past behaviors, and the analysis is inclined to delineate a tendency rather than to give a prediction.

Furthermore, mainly due to the lengthy low turnout, the political adaptation theory cannot be rigidly applied to understand Poland's party politics. In this aspect, as displayed in the article, the adaptation theory loosely applied can be taken as an acceptable tradeoff for the insight that it has revealed.

The EU is a normative power and its influence should be understood as a three-stage process, namely, norm emergence, norm cascade, and internalization (Finnemore and Sikkink 1998: 895). In this reading, the EU's impact evaluated at different stages is likely to lead to different conclusions. That being so, although the internalization of EU norms still asks for more time, the EU's pivotal roles have been attested in the stages of norm emergence and cascade. To further exploit the potential of EU norms, the following two points should be kept in mind.

Firstly, although the EU has no mandate to intervene member states' party politics, it can, however, make them more compatible with political parties' particular interests. In this regard, it is not easy, but not impossible, to balance between the EU's cosmopolitan norms and political parties' parochial interests. In any event, the EU is known for its capability of policy innovation. Apart from such capability, the urgency of doing so has also kept the policy innovation on the front burner. 
Alongside the growing decoupling of economic development and political conditionality, the EU should not be complacent with its economic governance anymore.

Secondly, a healthy civil society is conducive to hold a ruling party or a party coalition accountable. Civil society is a decisive part of societal variables, and the restoration of civil society can affect political parties' adaptation preferences bottom-up. Different from the direct and quick authority emanating from legally binding mandates, the civil society approach is slow but steady. In any event, so long as political parties have to draw their legitimacy in the domestic arena, the civil society can play such a role.

In describing the institutional design in the post-communist societies, Elster et al. (1998) analogized it to the rebuild of a ship at sea. In the ship-rebuilding process, although political parties play a steering role, the EU's impact is not necessarily limited. Furthermore, the EU, as an epistemic community, can make its norms congruent with political parties' interests, "and this is more likely to happen during a crisis, when knowledge promises better solutions to old problems" (Haas 1990: 45).

Funding This study was funded by China Scholarship Council (No. 201708060001).

Open Access This article is licensed under a Creative Commons Attribution 4.0 International License, which permits use, sharing, adaptation, distribution and reproduction in any medium or format, as long as you give appropriate credit to the original author(s) and the source, provide a link to the Creative Commons licence, and indicate if changes were made. The images or other third party material in this article are included in the article's Creative Commons licence, unless indicated otherwise in a credit line to the material. If material is not included in the article's Creative Commons licence and your intended use is not permitted by statutory regulation or exceeds the permitted use, you will need to obtain permission directly from the copyright holder. To view a copy of this licence, visit http://creativecommons.org/licen ses/by/4.0/.

\section{References}

Agh, A. 1998. The Politics of Central Europe. London: Sage Publications.

Batt, J., and K. Wolczuk. 1998. Redefining the state: the constitutional process. In Developments in Central and East European Politics 2, ed. S. White, J. Batt, and P.G. Lewis. London: Macmillan Press.

Beck, U., and Grande, E. 2007. Cosmopolitan Europe, trans. C. Cronin. Cambridge: Polity.

Blondel, J. 2002. Party government, patronage, and party decline in Western Europe. In Political Parties: Old Concepts and New Challenges, ed. R. Gunther, J. Ramon-Montero, and J.J. Linz. Oxford: Oxford University Press.

Börzel, T.A. 2016. From EU governance of crisis to crisis of EU governance: regulatory failure, redistributive conflict and Eurosceptic publics. Journal of Common Market Studies 54: 8-13.

Börzel, T.A., and T. Risse. 2007. Europeanization: the domestic impact of EU politics. In Handbook of European Union Politics, ed. K.E. Jorgensen, M. Pollack, and R. Ben. London: Sage.

Börzel, T.A., and T. Risse. 2012. From Europeanisation to diffusion: introduction. West European Politics 35 (1): 1-19.

Checkel, J. T. 2006. Constructivist approaches to European integration. Working Paper No. 06. ARENA and Department of Political Science University of Oslo.

Dalton, R.J., and S. Weldon. 2007. Partisanship and party system institutionalization. Party Politics 13 (2): 179-196.

Dean, D.G. 1960. Alienation and political apathy. Social Forces 38 (3): 185-189.

Delanty, G., and C. Rumford. 2005. Rethinking Europe: Social Theory and the Implications of Europeanization. London and New York: Routledge. 
Dorussen, H., and K. Nanou. 2006. European integration, intergovernmental bargaining, and convergence of party programmes. European Union Politics 7 (2): 235-256.

Elgie, R. 2010. Semi-presidentialism, cohabitation and the collapse of electoral democracies, 1990-2008. Government and Opposition 45 (1): 29-49.

Elster, J., C. Offe, U.K. Preuss, F. Boenker, U. Goetting, and F.W. Rueb. 1998. Institutional Design in Post-communist Societies: Rebuilding the Ship at Sea. Cambridge: Cambridge University Press.

Eriksen, E. O. 2019. Banishing dominance in Europe: the case for regional cosmopolitanism. European Journal of International Relations: 1-25.

European Commission. 2017. Rule of Law: European Commission Acts to Defend Judicial Independence in Poland. https://ec.europa.eu/commission/presscorner/detail/en/IP_17_5367. Accessed 24 March 2020.

Finnemore, M., and K. Sikkink. 1998. International norm dynamics and political change. International Organization 52 (4): 887-917.

Grzymala-Busse, A., and A. Innes. 2003. Great expectations: the EU and domestic political competition in East Central Europe. East European Politics and Societies 17 (1): 64-73.

Haas, E.B. 1968. The Uniting of Europe: Political, Social, and Economic Forces 1950-1957. Stanford: Stanford University Press.

Haas, E.B. 1990. When Knowledge is Power: Three Models of Change in International Organizations. Berkeley and Los Angeles: California University of California Press.

Haas, E. B. 1997. Nationalism, Liberalism, and Progress, Volume 1: The Rise and Decline of Nationalism. Ithaca and London: Cornell University Press.

Hanley, D. 2008. Beyond the Nation State: Parties in the Era of European Integration. Basingstoke: Palgrave Macmillan.

Hix, S., and C. Lord. 1997. Political Parties in the European Union. Basingstoke: Macmillan.

Jasiewicz, K. 1997. Poland: Walesa's legacy to the presidency. In Postcommunist Presidents, ed. R. Taras. Cambridge: Cambridge University Press.

Jasiewicz, K. 2008. The new populism in Poland: the usual suspects? Problems of Post-Communism 55 (3): 7-25.

Kamusella, T. 2017. The Un-Polish Poland, 1989 and the Illusion of Regained Historical Continuity. Cham: Palgrave Macmillan.

Kaufmann, D., and Kraay, A. 2019. Worldwide Governance Indicators. http://info.worldbank.org/gover nance/wgi/\#home. Accessed 10 March 2020.

Kaufmann, D., A. Kraay, and M. Mastruzzi. 2011. The Worldwide Governance Indicators: methodology and analytical issues. Hague Journal on the Rule of Laws 3: 220-246.

Kendall-Taylor, A., E. Frantz, and J. Wright. 2017. The global rise of personalized politics: it's not just dictators anymore. The Washington Quarterly 40 (1): 7-19.

Ladrech, R. 2002. Europeanization and political parties: towards a framework for analysis. Party Politics 8 (4): 389-403.

Ladrech, R. 2007. National political parties and European governance: the consequences of "missing in action". West European Politics 30 (5): 945-960.

Ladrech, R. 2009. Europeanization and political parties. Living Reviews in European Governance 4 (1): $4-21$.

Łaszczuk, A. 2015. A refugee debate. Radio Poland. http://archiwum.thenews.pl/1/6/Artykul/221501. Accessed 24 March 2020.

Lázár, N. 2015. Euroscepticism in Hungary and Poland: a comparative analysis of Jobbik and the Law and Justice Parties. Politeja Pismo Wydziału Studiów Międzynarodowych i Politycznych Uniwersytetu Jagiellońskiego 33: 215-233.

Lührmann, A., and S.I. Lindberg. 2019. A third wave of autocratization is here: what is new about it? Democratization 26 (7): 1095-1113.

Mair, P. 2000. The limited impact of Europe on national party systems. West European Politics 23 (4): 27-51.

Mair, P. 2007. Political parties and party systems. In Europeanization: New Research Agendas, ed. P. Graziano and M.P. Vink. Basingstoke: Palgrave Macmillan.

Markowski, R. 2016. The Polish parliamentary election of 2015: a free and fair election that results in unfair political consequences. West European Politics 39 (6): 1311-1322.

Markowski, R. 2020. Political systems, socio-economic development and the quality of democracy in CEE countries. In Social and Economic Development in Central and Eastern Europe: Stability and Change After 1990, ed. G. Gorzelak. London and New York: Routledge. 
Markowski, R., and J.A. Tucker. 2010. Euroscepticism and the emergence of political parties in Poland. Party Politics 16 (4): 523-548.

McNamara, K.R. 2015. The Politics of Everyday Europe: Constructing Authority in the European Union. Oxford: Oxford University Press.

Merlingen, M. 2007. Everything is dangerous: a critique of "normative power Europe". Security Dialogue 38 (4): 435-453.

Millard, F. 2006. Poland's politics and the travails of transition after 2001: the 2005 elections. EuropeAsia Studies 58 (7): 1007-1031.

Moravcsik, A. 1998. The Choice for Europe: Social Purpose and State Power from Messina to Maastricht. Ithaca: Cornell University Press.

Morlino, L. 2001. Constitutional design and problems in implementation in Southern and Eastern Europe. In Democratic Consolidation in Eastern Europe, Volume I: Intuitional Engineering, ed. J. Zielonka. New York: Oxford University Press.

Moroska, A., and K. Zuba. 2010. Two faces of Polish populism: the causes of the success and fall of Self Defence and the League of Polish Families. Totalitarismus und Demokratie 7 (1): 123-147.

Parrott, B. 1997. Perspectives on postcommunist democratization. In Conflict, Cleavage, and Change in Central Asia and the Caucasus, ed. K. Dawisha and B. Parrott. Cambridge: Cambridge University Press.

Pirro, A.L.P. 2014. Digging into the breeding ground: insights into the electoral performance of populist radical right parties in Central and Eastern Europe. East European Politics 30 (2): 246-270.

Rosenau, J. N. 1980. The Scientific Study of Foreign Policy. London: Frances Pinter (Publishers) Ltd.

Rosenau, J. N. 1981. The Study of Political Adaptation. London: Frances Pinter (Publishers) Ltd.

Saurugger, S. 2009. Sociological approaches in EU Studies. Journal of European Public Policy 16 (6): 935-949.

Schimmelfennig, F. 2016. Good governance and differentiated integration: graded membership in the European Union. European Journal of Political Research 55: 789-810.

Schweller, R.L. 1994. Bandwagoning for profit: bringing the revisionist state back in. International Security 19 (1): 72-107.

Smith, S.M. 1981. Traditionalism, behaviouralism and change in foreign policy analysis. In Change and the Study of International Relations: The Evaded Dimension, ed. B. Buzan and R.J.B. Jones. London: Frances Pinter (Publishers) Ltd.

Steves, F. 2001. Poland and the international system: external influences on democratic consolidation. Communist and Post-Communist Studies 34: 339-352.

Szczerbiak, A., and M. Bil. 2009. When in doubt, (re-)turn to domestic politics? the (non-)impact of the EU on party politics in Poland. Journal of Communist Studies and Transition Politics 25 (4): 447-467.

Thomas, M.A. 2010. What do the worldwide governance indicators measure? European Journal of Development Research 22 (1): 31-54.

Vachudova, M.A. 2008. Tempered by the EU? Political parties and party systems before and after accession. Journal of European Public Policy 15 (6): 861-879.

Venice Commission. 2009. Code of Good Practice in the Field of Political Parties. Study No. 414/2006, CDL-AD (2009) 002. https://www.venice.coe.int/webforms/documents/default.aspx?pdffile=CDLAD(2009)002-e. Accessed 24 March 2020.

Venice Commission. 2016. Rule of Law Checklist. Study No. 711/2013, CDL-AD (2016) 007. https:// www.venice.coe.int/webforms/documents/default.aspx?pdffile=CDL-AD(2016)007-e. Accessed 24 March 2020.

Visvizi, A., and P. Tokarski. 2014. Poland and the Euro: between lock-in and unfinished transition. Society and Economy 36 (4): 445-468.

Whitaker, R. 2005. National parties in the European Parliament: an influence in the committee system? European Union Politics 6 (1): 5-28.

Wronski, P. 2007. Premier: Wokół rezultatów szczytu UE panuje paranoja. In Gazeta Wyborcza, 7-8 July. Yu, B. 2019. From global governance to global disorder? Implications for Russia and China. In SinoRussian Relations in the 21st Century, ed. J.I. Bekkevold and B. Lo. Cham: Palgrave Macmillan.

Zuba, K. 2009. Through the looking glass: the attitudes of Polish political parties towards the EU before and after accession. Perspectives on European Politics and Society 10 (3): 326-349.

Pengfei Hou is a Ph.D. student from the School of International Relations, University of St Andrews. 